ADAM MIODOWSKI (Białystok)

\title{
WALKA PROPAGANDOWA WYCHODŹCZYCH UGRUPOWAŃ DEMOKRATYCZNYCH Z RZECZNIKAMI STWORZENIA POLSKIEGO WOJSKA W ROSJI (1917-1918)
}

Środowisko polskich demokratów w Rosji poczęło tworzyć pierwsze struktury organizacyjne u schyłku 1914 r. Wówczas to powstała w Kijowie Polska Grupa Demokratyczno-Niepodległościowa zrzeszająca działaczy o zapatrywaniach liberalno-demokratycznych. Równocześnie, na bazie struktur organizacyjnych Polskiego Towarzystwa Pomocy Ofiarom Wojny [dalej: PT POW $]^{1}$, powstały na początku $1915 \mathrm{r}$. w wielu rosyjskich miastach prowincjonalnych Komitety Polskie grupujące ten odłam wychodźczej inteligencji, który hołdował ideologii liberalno-demokratycznej. Pośród tych organizacji największą aktywność wykazał Komitet Polski w Moskwie utworzony z inicjatywy Aleksandra Lednickiego ${ }^{2}$ w oparciu o działające wcześniej stowarzyszenia: Katolickie Towarzystwo Dobroczynności i Dom Polski. Kolejną inicjatywą mającą na celu zintegrowanie organizacy jne rzesz zwolenników ideologii liberalno-demokratycznej w środowisku wychodźstwa polskiego w Rosji stało się powołanie jesienią 1915 r. Polskiego Zrzeszenia Niepodległościowego [dalej: PZN]. Z inicjatywą utworzenia tej konspiracyjnej organizacji wystąpili Aleksander Więckowski i Aleksander Babiański. Bazą społeczną

1 Organizacja ta powstała w sierpniu 1914 r. początkowo pod nazwą Towarzystwo Pomocy Rodzinom Rezerwistów Polskich i Ubogiej Ludności Polskiej, działając głównie w Piotrogrodzie. W krótkim jednak czasie, ze względu na rosnące potrzeby, rozciągnęła swą działalność na teren całej Rosji, stając się najpowszechniejszą i najbardziej masową organizacja polską w tym kraju. Spowodowało to zmianę nazwy organizacji na Polskie Towarzystwo Pomocy Ofiarom Wojny.

2 Szczegółowe informacje biograficzne dotyczące postaci A. Lednickiego podaje w swej publikacji Z. Nagórski: Aleksander Lednicki (1866-1934), „Zeszyty Historyczne” 1962 , z. 1 , s. $27-66$. 
PZN stało się stare wychodźstwo, przede wszystkim inteligencja, ale z czasem znaleźli się w nim przedstawiciele wychodźstwa wojennego oraz niektórzy członkowie Polskiej Partii Socjalistycznej Frakcji Rewolucyjnej [dalej: PPS FR], Polskiej Organizacji Wojskowej [dalej: POW], Polskiej Partii Socjalistycznej Lewica [dalej: PPS Lewica], ludowcy z Zarania ${ }^{3}$, a nawet z Socjaldemokracji Królestwa Polskiego i Litwy [dalej: SDKPiL] ${ }^{4}$. W efekcie środowisko demokratyczne w Piotrogrodzie zintegrowało się $\mathrm{z}$ grupami politycznymi stojącymi na gruncie rozwiązania austro-polskiego. Zwłaszcza przystąpienie do PZN członków POW, tj. Franciszka Skąpskiego i Juliusza Łukasiewicza, nadało mu jednoznacznie aktywistyczny charakter.

Polskie żywioły liberalno-demokratyczne skupione w konspiracyjnym PZN z chwilą obalenia rządu carskiego ujawniły swe istnienie i od 18.03. 1917 r. zaczęły funkcjonować pod nazwą Polskiego Komitetu Demokratycznego [dalej: PKD] ${ }^{5}$. Niebawem po lutowym przewrocie rewolucyjnym, bo już 20.03.1917 r., powstała w Moskwie kolejna struktura organizacyjna, która przyjęła nazwę Polskiego Klubu Demokratycznego. Jednym z jego założycieli był A. Lednicki ${ }^{6}$. Ruch demokratyczny zaczął się też rozwijać i na prowincji. Przykładem tego była inicjatywa polskiego ośrodka liberalno-demokratycznego na Białorusi, podjęta przez komitet organizacyjny powołany prawdopodobnie 20.03.1917 r. Faktyczne ukonstytuowanie się nowej organizacji, która przyjęła nazwę Polskiego Związku Demokratycznego [dalej: PZD] nastąpiło 1.04.1917 r. na zwołanym w Mińsku wiecu informacyjno-agitacy jnym. Prócz Piotrogrodu, Moskwy i Mińska w wielu innych miastach państwa rosyjskiego zaczęły powstawać nowe komitety, kluby, związki i zrzeszenia demokratyczne.

3 Tzw. zaraniarze byli radykalnymi działaczami chłopskimi skupiającymi się wokół ukazującego się w latach 1907-1915 tygodnika „Zaranie”.

4 Jeśli chodzi o działaczy SDK PiL to ich flirt ze środowiskiem demokratycznym był raczej przejściowy.

5 Do grupy organizacyjnej PKD weszli: A. Babiański, A. Lednicki, A. Więckowski, H. Gliwic, J. Dąbrowski, W. Rawicz-Szczerbo, K. Niedźwiedzki, F. Skąpski, S. Miciewicz, S. Filipkowski, S. Budkiewicz, J. Rokman, H. Piotrowicz, J. Łukasiewicz, B. Siwik, J. Barchwitz. Patrz: Kwestia wojska polskiego w Rosji w 1917 r., oprac. W. Szczęsny, Warszawa 1936, s. 23.

6 Członkami Rady Polskiego Klubu Demokratycznego w Moskwie byli: L. Darowski, J. Ewert, O. Fedorowicz, L. Fryze, Z. Raydel, J. Jakubowski, J. Karpowicz, F. Kierski, A. Lednicki, W. Mroczkowski, J. Podgórska, M. Róg, L. Walczewski, J. Szymański, L. Waserberger, A. Wierzchlejski, B. Wróblewski, ks. P. Zieliński i W. Świętosławski. Patrz: Kwestia wojska..., s. 84 . 
W pierwszej dekadzie maja 1917 r. proces tworzenia terenowych struktur organizacyjnych polskiego ruchu demokratycznego w Rosji wszedł w nową fazę. Związki, kluby i komitety demokratyczne zaczęły się stapiać $\mathrm{w}$ jednolite ugrupowanie polityczne o profilu liberalno-demokratycznym. Przełomowym momentem w procesie organizowania jednolitego ugrupowania demokratycznego w Rosji był zwołany w dniach 9-10.05.1917 r. w Moskwie I Zjazd Demokracji Polskiej. W trakcie obrad zjazdu wyłoniono swego rodzaju organ kierowniczy dla ogółu ugrupowań demokratycznych, w postaci Komitetu Demokratycznego. W jego składzie znaleźli się przedstawiciele głównych ośrodków organizacyjnych ruchu, a więc Piotrogrodu, Moskwy, Mińska, Kijowa i Charkowa?

W wyniku zaktywizowania się po lutowym przewrocie rewolucyjnym politycznych i wojskowych rzeczników tworzenia polskich formacji w Rosji, przed ugrupowaniami demokratycznymi stanął dylemat, sprzeciwić się, czy też poprzeć te dążenia. Wobec reprezentowanej przez demokratów aktywistycznej orientacji politycznej sprawa była $\mathrm{w}$ istocie $\mathrm{z}$ góry przesądzona. Przyjęcie odmiennego stanowiska oznaczałoby przyznanie, że na wychodźstwie też istnieje, lub może powstać, ośrodek władzy politycznej, posiadający prerogatywy reprezentacji ogólnokrajowej. Tymczasem demokraci za taki ośrodek władzy uznawali wyłącznie Tymczasową Radę Stanu [dalej: TRS], postrzegając tą instytucję jako najwyższy urząd państwowotwórczy i zaczątek przyszłego rządu polskiego ${ }^{8}$. Zatem tworzenie własnych jednostek na Wschodzie było w ich odczuciu wyłącznie uzależnione od woli Kraju. Wydaje się jednak, że pogląd demokratów na kwestię formowania polskiego wojska w Rosji wynikał nie tyle $z$ przeświadczenia, że aktywiści w Kraju tego sobie nie życzą ${ }^{9}$, ale przede wszystkim z obawy, że nie uda się wygrać rywalizacji ze Stronnictwem Narodowo-Demokratycznym [dalej: SND] o polityczne kierownictwo nad tym wojskiem. Wiosną $1917 \mathrm{r}$. wokół tej sprawy rozgorzała więc bezpardonowa walka propagandowa pomiędzy demokratami a endekami.

7 W skład Komitetu Demokratycznego wchodzili: z Piotrogrodu - A. Babiański, J. Dąbrowski, H. Gliwic, S. Mickiewicz, F. Skąpski, W. Rawicz-Szczebro; z Moskwy L. Darowski, F. Kierski, L. Wasserberger, W. Świętosławski; z Kijowa - E. Starczewski, K. Waligórski; z Charkowa - S. Hoffmokl; z Mińska - S. Kopciński. Patrz: A. Miodowski, Demokraci polscy w Rosji w latach 1917-1918, „Studia Podlaskie”. 1988, t. 8, s. 21.

8 Archiwum Akt Nowych. Gabinet Cywilny Rady Regencyjnej [dalej: AAN. GCRR]: dz. $445 /$ II, t. 34, k. 8 .

9 Podczas I Konferencji Sztokholmskiej to demokraci niemal wymusili na delegatach z Kraju deklarację sprzeciwiającą się formowaniu polskiego wojska w Rosji. 
Analizując przebieg tej walki, w pierwszym rzędzie należy zwrócić uwagę na działania propagandowe podjęte przez najpoczytniejsze organy prasowe ruchu demokratycznego, tj. „Dziennik Petrogradzki” i „Echo Polskie". Pierwsze $z$ wymienionych pism posiadało jeszcze przedrewolucyjny rodowód. Natychmiast po lutowym przewrocie rewolucyjnym, gazeta kierowana przez Jana Dąbrowskiego i Stefana Grosterna stała się półoficjalnym organem nowo utworzonego wówczas Polskiego Komitetu Demokratycznego. Jednakże w wyniku pewnych perturbacji organizacyjno-finansowych od $1.08 .1917 \mathrm{r}$. gazeta przestała się nagle ukazywać, by po miesięcznej przerwie powrócić pod zmienionym tytułem „Dziennik Narodowy”. Od tej pory wydawcą i redaktorem naczelnym pisma był F. Skąpski, pełniący m.in. funkcję dowódcy POW na Rosję. Zmiany te nie odbiły się jednak w widoczny sposób na linii programowej dziennika, zacieśniły tylko mocniej jego związki ze środowiskiem peowiackim.

Przedrewolucyjny rodowód posiadało również założone przez A. Lednickiego we wrześniu 1915 r. „Echo Polskie”, które po lutowym przewrocie rewolucyjnym stało się organem moskiewskiego Polskiego Klubu Demokratycznego. Założyciel pisma po objęciu funkcji prezesa Komisji Likwidacyjnej do Spraw Królestwa Polskiego [dalej: KLdSKP] wycofał się formalnie z zespołu redakcyjnego, choć nie przestał zamieszczać w nim własnych publikacji. Od jesieni 1917 r. redaktorem naczelnym pisma został zaufany lidera moskiewskich demokratów, Feliks Kierski.

Wymienione tytuły pod jęły generalny szturm do serc, sumień i rozsądku swoich czytelników, by przekonać ich o szkodliwości tworzenia armii narodowej na Wschodzie. W tej szalonej i nie przebierającej w środkach agitacji mieszano kłamstwa z prawdą, nadużywano słów i uczuć, zawsze przy tym powołując się na dobro ojczyzny. Charakterystyczną cechą podjętej przez demokratów kampanii prasowej w sprawie polskiego wojska było ogromne jej przesycenie treściami emocjonalno-patriotycznymi. Bezpośrednie rezultaty tej niezwykle intensywnej i zróżnicowanej w środkach propagandy, były względnie nikłe. Nie znaczy to jednak, by wśród mas wychodźczych nie pozostawiła ona trwałych śladów.

Prasa demokratyczna od razu uznała endeckie zabiegi wokół tworzenia polskiego wojska za przygotowania do masowego bratobójstwa. Kamieniem węgielnym polityki ugrupowań demokratycznych w Rosji było wszak założenie, że „Polska to jest w obecnej chwili Królestwo Polskie jako niepodległe, posiadające własny rząd, jedynie mające prawo głosu w imieniu całej Polski, poza tym tego prawa nie może mieć nikt, a tym mniej Polacy Rosję zamieszkujący. Wychodząc z tej zasady, dla wszystkich Polaków na całej 
kuli ziemskiej rządem polskim może tylko być [Tymczasowa] Rada Stanu w Warszawie" 10.

Do najgłośniejszych antyendeckich wystąpień publicystycznych, z uwagi na osobę autora i temperament polemiczny, należały dwa cykle artykułów Jana Baudouina de Courtenay, zamieszczone w czerwcu 1917 r. w „Dzienniku Petrogradzkim" pod znamiennymi tytułami: Nienawiść i wzgarda dla koalicji oraz $Z$ powodu polskich sit zbrojnych. W pierwszym $\mathrm{z}$ nich autor $\mathrm{z}$ pasją wykazywał dwulicowość polityki państw zachodnioeuropejskich, które niezależnie od składanych oświadczeń w praktyce sprawę polską zawsze uważały za wewnętrzny problem Rosji. Przestrzegał również, aby zapewnienia koalicji o zjednoczeniu wszystkich ziem polskich, nawet z Gdańskiem, traktować ostrożnie i z nieufnością, gdyż jest to ze strony koalicji manewr strategiczny obliczony na przedłużenie wojny ${ }^{11}$. W drugim cyklu, uznając proklamację Rządu Tymczasowego za akt anulujący traktaty wiedeńskie i zwalniający Polaków od poddaństwa rosyjskiego, J. Baudouin de Courtenay występował $\mathrm{z}$ twierdzeniem, że istnienie niezależnego państwa polskiego wyklucza możliwość tworzenia polskiego wojska w ramach armii rosyjskiej ${ }^{12}$. Nie szczędził też autor w obu publikacjach złośliwych aluzji pod adresem działaczy piotrogrodzkiego KNP.

$\mathrm{Z}$ innymi argumentami wystąpił J. Dąbrowski w artykule Do Zjazdu Wojskowych Polaków w Piotrogradzie. Najpierw odwołał się do zdyscyplinowania i karności żołnierzy, pisząc: „[...] nie nam zapatrywać się na to, co zachodzi w rosyjskiej masie żołnierskiej i nie stamtąd brać przykłady. Ale wpływ otoczenia jest tak nieraz silny, że nawet znając jego wady niepodobna ustrzec się od ich naśladowania. Dlatego z niepokojem czekamy waszych słów i postanowień, obawiając się, abyście wzorem tych pułków, co na własną rękę zawierały pokój, nie poczęli na własną rękę podejmować działań [...]. Żołnierz nie politykuje, żołnierz słucha swego rządu [...] nigdy mu do głowy nie przyjdzie, aby wiecować i decydować". Autor ponadto straszył w swej publikacji czytelników konsekwencjami stworzenia polskiego wojska w Rosji, pisząc: „[...] z chwilą gdy tu, na gruncie rosyjskim my Polacy, zerwiemy z polityką neutralności, jaką obrał sobie kraj, Polska [...] znajdzie się właśnie $\mathrm{w}$ tej chwili $\mathrm{w}$ otwartej wojnie $\mathrm{z}$ państwami centralnymi [...], a wówczas pozostawałaby nadzieja tylko na akcję wojskową na froncie rosyjskim,

10 „Dziennik Petrogradzki” z 9.05.1917 r.

11 „Dziennik Petrogradzki” z 28.06.1917 r.

12 „Dziennik Petrogradzki” z 17.06.1917 r. 
o której wiecie wszyscy doskonale, że niepodobna pokładać w niej przesadnych nadziei" 13 . W przytoczonych wywodach zawarte zostały zasadnicze argumenty, przy pomocy których działacze demokratyczni zwalczali tworzenie polskiego wojska w Rosji. Wypowiedzi tego typu nadawały kierunek prowadzonej przez ugrupowania demokratyczne propagandzie skierowanej zarówno przeciwko idei polskiego wojska w Rosji, jak i jej rzecznikom.

W przeciwieństwie do „Dziennika Petrogradzkiego”, organ moskiewskich demokratów „Echo Polskie” z racji swych nieformalnych powiązań z A. Lednickim zwalczał ideę polskiego wojska w Rosji, posługując się nieco mniej agresywną retoryką. Przykładem tego bardziej umiarkowanego tonu propagandowego niech będzie publikacja poświęcona wyborowi J. Piłsudskiego na honorowego przewodniczącego Ogólnego Zjazdu Wojskowych Polaków. Fakt powierzenia tej funkcji brygadierowi posłużył gazecie za pretekst, by w ironicznej konwencji spróbować zdyskredytować zarówno ideę polskiego wojska, jak i jej politycznych rzeczników. Organ moskiewskich demokratów pokpiwał sobie, stwierdzając m.in.: „Tyle argumentów zużyła grupa narodowo-demokratyczna, usiłująca na emigracji prowadzić oderwaną od kraju politykę dla udowodnienia, że Polacy tutaj mają prawo, że powinni nawet iść za jej wskazaniami. [...] Z takim kunsztem łączono tą argumentację z hasłami rewolucyjnymi, co ze strony grupy narodowo-demokratycznej było prawdziwym poświęceniem [...]. Równocześnie dyskredytu jąc akcję prowadzoną w kraju. [...] I nagle taki przykry wypadek. Tak nieprzewidziana uchwała, głosząca, że prezesem honorowym Zjazdu jest Józef Piłsudski. [...] $\mathrm{Na}$ nic nie zdała się kilkutygodniowa agitacja, w niwecz obróciły się nadzieje i apetyty na rolę rządu narodowego w stosunku do armii polskiej w Rosji, prysły marzenia o powrocie do władzy za pomocą szabel polskich" ${ }^{14}$.

Po czerwcowym Ogólnym Zjeździe Wojskowych Polaków w Piotrogradzie, na którym podjęto formalną decyzję organizowania polskich formacji wojskowych w Rosji, prasa demokratyczna przestała się przeciwstawiać samemu ich organizowaniu. Ostrze swoich ataków skierowała natomiast przeciwko wyłonionemu na zjeździe Naczelnemu Polskiemu Komitetowi Wojskowemu [dalej: NPKW], domagając się poddania polskiego wojska właściwemu kierownictwu politycznemu. Organem, który mógł to zagwarantować, był w opinii demokratów, wyłoniony na tzw. I Zjeździe Lewicy Wojskowej Komitet Główny Związku Wojskowych Polaków Lewicy [dalej: KG ZWPL].

13 Kwestia wojska..., s. 118 i n.

14 „Echo Polskie”, nr 123 z 9.06.1917 r. 
Ponieważ działalność tej instytucji, na którą demokraci posiadali znaczny wpływ, nie miała większego zasięgu, prasa demokratyczna zaczęła lansować projekt powołania przy Rządzie Tymczasowym specjalnego Komisariatu do Spraw Wojskowych Polaków. Inicjatywa ta, co zrozumiałe, była zwalczana zarówno przez propagandę endecką, jak też i przez prasę wojskową związaną z NPKW.

Wszelkie poczynania publicystyczne demokratów, bez względu na to, czy posiadały otwarty, czy też ukryty charakter, były siłą rzeczy wyjątkowo niezręczne. Ogół społeczności polskiej w Rosji dostrzegał bowiem w tych poczynaniach środowiska demokratycznego ową trudną do pogodzenia dwutorowość, wyrażającą się w występowaniu zasadniczej sprzeczności pomiędzy utrzymywaniem jak najlepszych stosunków z Rządem Tymczasowym, przy równoczesnym realizowaniu instrukcji pochodzących $z$ drugiej strony frontu. Dowodem na to, że środowiska wychodźcze w Rosji doskonale ów dysonans dostrzegały była nikła skala poparcia dla linii politycznej demokratów. Dodać w tym miejscu wypada, iż chęć utrzymania przez prasę demokratyczną w Rosji, wychodźstwa w przekonaniu o jednolitej woli Kraju, bez zastrzeżeń jakoby popierającego TRS, była wyraźnym wypaczeniem rzeczywistości. Wypominała to demokratom prasa endecka, która po pierwsze stale kwestionowała legalność TRS jako instytucji ustanowionej przez pozbawione mocy prawnej decyzje okupantów, a po drugie stale donosiła o niepodległościowych, antyniemieckich nastrojach w Polsce, wyłamującej się z przymusowej neutralności.

Pisma endeckie począwszy od wiosny 1917 r. zaczęły usilnie na swych łamach propagować ideę utworzenia polskich formacji wojskowych na gruncie rosyjskim. Argumentacja przytaczana przez dwa czołowe organy prasowe obozu narodowego, tj. „Dziennik Polski” i "Gazetę Polską”, miała za zadanie dowieść, że niezależność państwową może Polska odzyskać jedynie w wyniku militarnej klęski Niemiec, rozbitych przez Ententę. W świetle tych założeń udział polskiego wojska $\mathrm{w}$ zmaganiach $\mathrm{z}$ Niemcami stawał się naglącą koniecznością, gdyż podczas konferencji pokojowej tylko taki argument mógł uzasadnić prawo Polski do skorzystania z owoców osiągniętego wspólnie zwycięstwa. Charakterystyczną cechą kampanii propagandowej, podjętej przez politycznych rzeczników stworzenia polskiego wojska w Rosji, było ogromne jej przesycenie treściami emocjonalno-patriotycznymi. W pismach wydawanych przez to środowisko, oprócz płomiennych wezwań przypominających o moralnym nakazie wstępowania do formacji polskich, roiło się od 
przeróżnych wspomnień, szkiców i gawęd wskrzeszających najdramatyczniejsze epizody tysiącletnich zmagań polsko-niemieckich. Nie unikano też zamieszczania listów domagających się ogólnonarodowego czynu zbrojnego. Najchętniej publikowano te $z$ nich, które przysyłali przedstawiciele środowiska weteranów $1863 \mathrm{r}$.

Należy jednak dostrzec i to, że pojawiały się również publikacje odznaczające się rzeczowym charakterem, wskazu jące na ekonomiczne i polityczne korzyści wynikające z rozbicia Niemiec. Do tej właśnie grupy wypowiedzi prasowych zaliczyć wy pada publikację zamieszczoną na łamach „Gazety Polskiej”, w której przeprowadzono rachunek korzyści i strat, jakie mogłyby się stać udziałem Polski w przypadku zwycięstwa jednej bądź drugiej strony światowego konfliktu. W przypadku zwycięstwa państw centralnych, gazeta przewidywała, że Polska otrzyma „[...] jakiś samodzielny ustrój polityczny na terenie dziewięciu czy ośmiu guberni Królestwa Polskiego, powiększonych może przez niektóre powiaty guberni grodzieńskiej. [...] Taka samodzielna Polska nawet $\mathrm{z}$ własnym królem na czele, wtłoczona pomiędzy państwa centralne, byłaby całkowicie od nich zależna zarówno pod względem gospodarczym, jak i militarnym. Pierwszym i koniecznym następstwem tej zależności stałoby się zrujnowanie przemysłu Królestwa”. Zdaniem gazety „Niemcy nie pozwolą nigdy na to, by Polska zabezpieczyła byt i rozwój swojego przemysłu przez cła zabezpieczające go od strony Niemiec. Ruina przemysłu pociągnie za sobą konieczność emigracji z Polski całego proletariatu robotniczego, a więc ubytek $\mathrm{z}$ kraju kilkunastu procent ludności rdzennie polskiej". Ten wątek rozważań zamknięty został konkluzją, z której wynikało, że „Rozwiązanie kwestii polskiej w myśl [powyższych - dop. A.M.] planów i zamiarów państw centralnych jest dla nas absolutnym złem, [gdyż - dop. A.M.] pomimo wszelkich pozorów i dekoracji niepodległościowych, zawiera ono w sobie niebezpieczeństwa, zagrażające wprost dalszemu istnieniu naszego narodu. [...] grozi bowiem rozsadzeniem największego naszego bloku etnograficznego, opartego o średni bieg Wisły". W drugiej części cytowanego artykułu przedstawiono z kolei korzyści, jakie odnieść mogłaby Polska, wiążąc swe niepodległościowe aspiracje ze zwycięstwem Ententy. „Jeżeli zwycięży Koalicja będziemy mieli Polskę niepodległą i zjednoczoną, bo to nam przyznały Rosja, Anglia, Francja i Włochy”. Zdaniem gazety „[...] rozwiązanie koalicyjne niepodległość Polski zjednoczonej nie tylko utrwala i umacnia [...] ale też daje Polsce wolny oddech przez dostęp do morza [...]. Nie mamy więc wyboru. Mamy przed sobą jedną tylko, jedyną prostą i jasną drogę, poparcie wszelkimi siłami koalicji antyniemieckiej, wytężenie wszystkich sił, by ta koalicja zwyciężyła. Idzie tu o przyszłość, być albo nie być całego na- 
rodu polskiego". Konsekwencją powyższych konstatacji było uznanie przez gazetę, że „Jednym ze środków zabezpieczenia sobie tej przyszłości, może nawet jedynym środkiem naprawdę ważkim i realnym jest zgromadzenie polskich sił zbrojnych po tej stronie kordonu wojennego w wielkich jednostkach bojowych" 15 .

Ta sama "Gazeta Polska” w ramach prowadzonej kampanii propagującej ideę stworzenia polskiego wojska w Rosji rozprawiła się również z podnoszonym przez demokratów koronnym argumentem, że polskie formacje mógłby utworzyć tylko prawowity rząd polski, a skoro takowy nie istnieje nie może też być mowy o organizowaniu tych formacji. Polemizując $z$ powyższą argumentacją, redaktor Antoni Sadzewicz w jednym ze swych artykułów wskazał m.in. na to, że oparta jest ona na teoretyczno-formalnych przesłankach. Autor stwierdził ponadto, że jakkolwiek stanowisko demokratów jest „[...] teoretycznie słuszne [to - dop. A.M.] w praktyce prowadzi do absurdu, oznacza ono bowiem, że naród który utracił swą niepodległość i prawowitego rządu nie posiada, nie może odzyskać tej niepodległości nigdy. Wszelkie bowiem wysiłki i zabiegi w imię odzyskania tej niepodległości podejmowane, muszą mieć charakter samozwańczy, nie mogą bowiem posiadać sankcji prawowitego rządu narodowego". W związku z powyższym, jak konstatował A. Sadzewicz, „Wychodząc z założenia tego teoretycznego legitymizmu musielibyśmy uznać za czyny niewłaściwe i niedopuszczalne nie tylko wszelkie zabiegi podejmowane $\mathrm{w}$ sprawie polskiej na gruncie państw zagranicznych [...], ale zakwestionować nawet pracę naszą nad organizowaniem szkolnictwa, bo przecież nie mamy prawowitego ministerium oświecenia publicznego [...]. Jest to oczywiście absurd, którego źródło tkwi w tym, że naród w naszej sytuacji będący nie może czekać sankcji dla podejmowanych prac i wysiłków, mających właśnie na celu odzyskanie niepodległości, od swego rządu prawowitego, który właśnie powstać i zorganizować się musi dopiero po odzyskaniu niepodległości". W dalszej części cytowanej publikacji autor rozprawił się również z podnoszoną przez demokratów wątpliwością, czy wychodźstwo w Rosji może stworzyć polskie wojsko bez uzyskania aprobaty TRS? W opinii redaktora "Gazety Polskiej”, rozpatrując to zagadnienie trzeba mieć na uwadze fakt, że „Kraj nasz znajduje się pod stopą okupacyjnych wojsk niemieckich i austriackich i swobodnie wypowiedzieć się w tej kwestii nie może". W związku z powyższym TRS nie jest w stanie „[...] wypowiedzieć się za tworzeniem armii polskiej po tej stronie kordonu

15 AAN. CAP: pudło 9, „Gazeta Polska” z 6.05.1917 r., k. 98. 
bojowego, armii która miałaby na celu walkę z Niemcami o zjednoczenie ziem polskich. Gdyby zaś TRS wypowiedziała się nawet przeciwko tego rodzaju zamiarom czy zabiegom, opinia jej nie posiada bynajmniej powagi decydującej instancji narodowej". Nie ulega bowiem wątpliwości, zdaniem A. Sadzewicza, że TRS jest tylko i wyłącznie organem pomocniczym wojskowych władz okupacyjnych. „Nazywanie tedy TRS rządem narodowym jest krzyczącym nonsensem i karygodnym bałamuceniem naszej opinii publicznej”. Skoro zaś sprawy tak właśnie się mają to „[...] przeto pożądane jest zgromadzenie w wielkich jednostkach bojowych tych sił polskich, które są rozproszone dzisiaj w armii rosyjskiej" ${ }^{16}$.

Kampanii propagandowej prowadzonej przez pisma politycznych rzeczników stworzenia polskiego wojska w Rosji wtórowały wydawnictwa wojskowe skupione wokół NPKW i uznających go terenowych Związków Wojskowych Polaków [dalej: ZWP]. Pojawienie się na rynku wydawniczym prasy wojskowej było naturalną konsekwencją powszechnej aktywizacji środowiska wojskowych Polaków służących w armii rosyjskiej. Spośród założonych w okresie od marca do października 1917 r. czasopism przeznaczonych dla tego kręgu odbiorców, największym wzięciem w środowisku żołnierskim cieszyły się cztery tygodniki: „Wiadomości Wojskowe”, „Żołnierz Polski”, „Polskie Siły Zbrojne” i „Rewolucyjna Armia Polska”. Oprócz tych czterech najpoczytniejszych tytułów ukazywało się jeszcze kilka efemerycznych wydawnictw poszczególnych ZWP. Pośród nich na uwagę zasługują: „Biuletyn Zarządu ZWP II Armii”, „Wiadomości Tygodniowe ZWP IX Armii” i „Głos ZWP Frontu Rumuńskiego”. Znaczenie tej drugiej grupy wydawnictw nie było nazbyt duże, gdyż ich oddziaływanie nie wykraczało poza ramy macierzystych formacji wojskowych ${ }^{17}$. Znamienną rzeczą jest, że wymieniona powyżej grupa najpoczytniejszych tygodników wydawana była wyłącznie pod auspicjami wojskowych rzeczników tworzenia polskich formacji w Rosji. Na łamach tych pism podjęto zatem szeroko zakrojoną kampanię propagandową, mającą na celu przede wszystkim przekonanie żołnierzy Polaków do poparcia idei polskiego wojska w Rosji, jak też zdyskredytowanie wrogów tej idei. Przeciwników tych upatrywano zarówno w kręgach politycznych, głównie środowisku demokratycznym, jak też i kręgach wojskowych, skupiających

16 AAN. CAP: pudło 9, „Gazeta Polska” z 5.05.1917 r., k. 97.

17 A. Ślisz, op. cit., s. 148. 
się wokół KG ZWPL. Ci ostatni do chwili pojawienia się jesienią $1917 \mathrm{r}$. własnego tygodnika w postaci „Sprawy Żołnierskiej” mogli prowadzić swoją kampanię propagandową wyłącznie za pośrednictwem wydawnictw prasowych, pozostających w dyspozycji politycznych przeciwników idei polskiego wojska. Nie oznaczało to w żadnym wypadku osłabienia siły ich negatywnego oddziaływania na rzesze wojskowych Polaków, gdyż ten chwilowy brak własnego organu prasowego nadrabiali bezpośrednią agitacją w jednostkach wojskowych, co też przynosiło wymierne rezultaty.

Pośród pism firmowanych przez wojskowych rzeczników tworzenia polskich formacji w Rosji jako pierwsze ukazywać się zaczęły „Wiadomości Wojskowe" wydawane od marca do września 1917 r. w Kijowie, a następnie w Mińsku. Funkcję redaktora naczelnego tygodnika przez cały ten czas pełnił ppor. H. Bagiński. Oficjalnym wydawcą pisma było Towarzystwo Polskiej Wiedzy Wojskowej wyrosłe na gruncie założonej w 1915 r. z inicjatywy Zygmunta Balickiego Biblioteki Wiedzy Wojskowej. Nieoficjalny patronat nad tygodnikiem sprawowała natomiast grupa członków Polskiej Ligi Wojennej Walki Czynnej, wywodząca się z byłej galicyjskiej organizacji pod nazwą Armia Polska ${ }^{18}$. „Wiadomości Wojskowe”, propagując ideę stworzenia polskiego wojska w Rosji, stosunkowo mało miejsca poświęcały na swych łamach tematyce społeczno-politycznej, koncentrując się niemal wyłącznie na zagadnieniach stricte wojskowych. Popularyzowano więc zarówno historię wojskowości polskiej, jak i różne zagadnienia z zakresu teorii oraz praktyki sztuki wojennej. Do piotrogrodzkiego Ogólnego Zjazdu Wojskowych Polaków pismo wypełniało rolę łącznika między poszczególnymi ZWP, m.in. publikując na swoich łamach podejmowane przez poszczególne związki uchwały i deklaracje. Od października 1917 r. po przeniesieniu redakcji z Kijowa do Mińska „Wiadomości Wojskowe” ukazywały się dzięki wsparciu finansowemu dowództwa I Korpusu Polskiego, choć formalnym wydawcą nadal pozostawało Towarzystwo Polskiej Wiedzy Wojskowej.

Pomimo że tematyka społeczno-polityczna nie zajmowała poczesnego miejsca na łamach „Wiadomości Wojskowych”, to zdarzało się nieraz, że redakcja zmuszona była angażować się $\mathrm{w}$ polemikę $\mathrm{z}$ pismami demokratycznymi, z reguły tendencyjnie odnoszącymi się do zagadnienia polskiego wojska w Rosji. Tak też było i w przypadku reakcji na publikację „Echa Polskiego", które zarzuciło moskiewskiemu ZWP, iż wykorzystuje struktury

18 H. Hubicka, Na Wschodniej rubieży. Stużba ojczyźnie. Wspomnienia uczestniczek walki o niepodlegtość 1915-1918, Warszawa 1929, s. 313. 
związkowe do organizowania formacji wojskowych, określając przy tym te działania jako „[...] wynaturzenie najszlachetniejszych instynktów i najszlachetniejszych odruchów" żołnierzy Polaków. Zdaniem organu moskiewskich demokratów, wojskowi Polacy nie po to organizowali się w związki, by na ich bazie tworzyć narodowe formacje. „Nie mają do tego prawa, ani możności. Tworzenie armii jest atrybutem całego społeczeństwa i całego narodu. [...] Jesteśmy pod tym względem tu na wychodźstwie w sytuacji niezmiernie trudnej. Musimy w naszych poczynaniach politycznych podporządkować się bezwzględnie temu co się dzieje w kraju. Kraj zaś ma obecnie zakneblowane usta i zupełnie nie może się wypowiadać19. A przecież armię polską może utworzyć przede wszystkim tylko Polska, Polska cała i Polska na miejscu". Powyższe wywody spotkały się ze zdecydowaną odpowiedzią "Wiadomości Wojskowych”, na łamach których stwierdzono m.in. „Echo wychodząc $\mathrm{z}$ faktu, że kraj ma usta zakneblowane, propaguje zupełną bierność, a w ten sposób zdanie całej sprawy polskiej na zrządzenie losu. Nieraz mamy w dziejach przykłady, że na emigracji kuto żelazo, aby rozkuć okowy spowijające ziemie ojczyste. Kraj ma obecnie zakneblowane usta, ale wypowiadał się aż nadto jasno aż do okupacji przez Niemców. I dzisiaj, urządzając manifestacje $\mathrm{z}$ hołdem Wilsonowi i Stanom [Zjednoczonym - dop. A.M.] przemawia w tym samym duchu, co w roku 1914 i 1915. [...] Czy to nie jest wymowa kraju?" 20. Ta i jej podobne publikacje „Wiadomości Wojskowych" wpisywały się w cały szereg publicystycznych wystąpień prasy wojskowej, która dawała odpór propagandzie demokratycznej zwalczającej ideę polskiego wojska w Rosji.

W przeddzień Ogólnego Zjazdu Wojskowych Polaków ukazał się pierwszy numer tygodnika „Armia Polska”. Począwszy od drugiego numeru aż do września 1917 r. pismo wychodziło już pod rozszerzonym tytułem „Rewolucyjna Armia Polska". Zmianę tytułu redakcja uzasadniła w nieco mętny sposób, stwierdzając m.in. „My rewolucjoniści, nadstawiając pilnie ucho na wszystko, co się dzieje w ojczyźnie i we wszechświecie, ażeby z przyczyn politycznych nie psuć sprawy [Tymczasowej- dop. A.M.] Radzie Stanu w kraju, stawiamy rzecz jeszcze jaśniej i oświadczamy, że Armia Polska powinna połączyć zbiorowo nie tylko siły zbrojne, pracy, nauki, polityki, społeczne,

19 Cytowana publikacja „Echa Polskiego” ukazała się przed I Konferencją Sztokholmską stąd pojawił się tu argument o zakneblowanych ustach Kraju. Po konferencji, gdy demokraci poznali stanowisko TRS mogli już mówić o sprzeciwie Kraju wobec idei tworzenia polskiego wojska w Rosji.

20 AAN. CAP: pudło 9, „Gazeta Polska” z 10.05.1917 r., k. 112. 
techniczne itd., lecz w ogóle wszystkie te siły, które stoją na gruncie rewolucyjnym. Rewolucyjny zakres Polaków na emigracji wyklucza wszelką politykę w dziedzinie, której carowie Wilhelm lub Karol mogliby rościć pretensje do [Tymczasowej - dop. A.M.] Rady Stanu" 21. Niewiele z tego uzasadnienia można zrozumieć i jak się wydaje redakcji o to właśnie chodziło. Celowe posługiwanie się mało precyzyjnym językiem stanowiło swego rodzaju wyróżnik tego tygodnika stworzonego faktycznie przez endecję, a formalnie redagowanego przez grono niepogodzonych $z$ ustaleniami I Konferencji Sztokholmskiej socjalistów z Adolfem Skobiejką na czele. Można wręcz zaryzykować tezę, że poprzez uruchomienie takiego pisma jak „Rewolucyjna Armia Polska" rzecznicy stworzenia polskiego wojska w Rosji powołali do życia swego rodzaju atrapę pisma radykalnego. Istnienie tego typu wydawnictwa skierowanego do politycznie mniej wyrobionych czytelników, realnie ograniczyło grono żołnierzy sięgających po właściwe organy polskiej lewicy rewolucyjnej, chroniąc tym sposobem rzesze wojskowych Polaków przed dalej posuniętą rewolucyjną demoralizacją. Osiągnięcie powyższego celu nie było chyba trudne, skoro ci, do których pismo było adresowane, z trudem lub wcale nie dostrzegali, że zajmowane przez tygodnik stanowisko we wszystkich zagadnieniach politycznych pokrywało się w istocie z linią Rady Polskiej Zjednoczenia Międzypartyjnego [dalej: RPZM], a rewolucyjne frazesy spełniały tylko rolę zasłony dymnej.

Począwszy od lipca 1917 r. ukazywał się w Mińsku wydawany przez Wydział Oświaty ZWP Frontu Zachodniego tygodnik „Żołnierz Polski”. Założycielem i redaktorem prowadzącym pismo był Henryk Nowodworski. Rozpowszechniane bezpłatnie wśród członków ZWP, wydawnictwo stało na gruncie realizacji uchwał Ogólnego Zjazdu Wojskowych Polaków, swoją misję widząc w dostarczeniu takich treści, przy których „[...] znalazłaby wytchnienie i wypoczynek poczciwa myśl polska, znękana nieraz bardzo tułaczką i trudami wojny, jak i [...] szczwaniami agitatorów partyjnych". Dopiero w takiej atmosferze, zdaniem redaktorów tygodnika, pojawić się mogła szansa, by z powodzeniem rozbudzić „,...] przygaszone iskierki poczucia patriotyzmu i ducha obywatelskiego" 22 . Do realizacji tak nakreślonych zadań zabrano się $z$ dużą zręcznością, dostosowując profil pisma do poziomu typowego czytelnika w mundurze. Redakcja, promując ideę stworzenia polskiego wojska w Rosji, nie ograniczała się wyłącznie do publikacji artykułów poli-

21 „Rewolucyjna Armia Polska”, nr 3 z 8.07.1917 r.

22 „Żołnierz Polski”, nr 58 z 15.06.1918 r. 
tycznych, zamieszczając na łamach tygodnika również teksty gawęd historycznych i patriotycznych utworów literackich. Publikowano zatem utwory wybitnych poetów i prozaików, aby poprzez oddziaływanie na sferę emocjonalną zachęcić żołnierzy Polaków do wstępowania do formacji narodowych, a tym samym uchronić ich przed wpływem agitacji rewolucyjnej. Tą właśnie propagandę uznawał tygodnik za najgroźniejszą przeszkodę w organizowaniu polskiego wojska w Rosji i zwalczał ją począwszy od pierwszego numeru. Wraz z wydawnictwami związanymi ze środowiskiem politycznych rzeczników tworzenia polskich formacji, tygodnik „Żołnierz Polski” demaskował poczynania zarówno rosyjskiej, jak i polskiej lewicy rewolucyjnej. Wiele uwagi poświęcano też na łamach pisma ocenie działań podejmowanych przez ugrupowania demokratyczne, równie usilnie zdaniem redakcji przeciwdziałające tworzeniu polskiego wojska. Jesienią $1917 \mathrm{r}$., w rezultacie aktywności właśnie tych środowisk, pojawiła się groźba zamknięcia tygodnika, gdyż ZWP Frontu Zachodniego „[...] zmieniwszy skład swego zarządu [...] nie szczędził «Żołnierzowi Polskiemu» kłopotów. Zaczęły się brutalne propozycje usunięcia z lokalu, zakusy o zagarnięcie czcionek [...]. Niemiłe stosunki, jakie zapanowały w ówczesnym Związku, zmusiły redakcję do przeniesienia się gdzie indziej" 23. Nowym wydawca pisma stał się od grudnia 1917 r. NPKW.

Organem prasowym wyłonionej na Ogólnym Zjeździe Wojskowych Polaków centrali związkowej był początkowo ukazujący się w Piotrogrodzie tygodnik „Polskie Siły Zbrojne”. Pismo redagowane było przez zespół pracowników Wydziału Prasowego NPKW, którym kierował chor. Kazimierz Bisping. Podstawowym zadaniem tygodnika stało się przekazywanie informacji o działalności NPKW, Zarządu Centralnego Związków Wojskowych Polaków [dalej: ZC ZWP] i Polskiego Wojskowego Komitetu Wykonawczego [dalej: PWKW]. „Polskie Siły Zbrojne” redagowane były w ten sposób, że zamieszczały na swych łamach publikacje w ramach dwóch stałych działów tematycznych. W dziale urzędowym umieszczano zarządzenia, komunikaty i odezwy wymienionych powyżej instytucji, zaś w dziale nieurzędowym ukazywały się artykuły publicystyczne, korespondencje i bieżące informacje. Tygodnik wydawany był bardzo krótko, bo tylko od końca sierpnia do połowy listopada $1917 \mathrm{r}$. W tym czasie redakcja konsekwentnie realizowała zadeklarowaną już w pierwszym numerze pisma linię programową, która zakładała, że „Polskie Siły Zbrojne”, podobnie jak instytucje wyłonione na Ogólnym Zjeździe Wojskowych Polaków, „[...] żadnemu stronnictwu, żadnej 
formule, żadnej doktrynie hołdować nie będą" ${ }^{24}$. Nie oznaczało to jednak, że tygodnik zamierzał ignorować oszczerczą kampanię prasy demokratycznej i lewicowej skierowaną przeciwko wojskowym rzecznikom tworzenia polskich formacji w Rosji. Na swoich łamach zamieszczał więc publikacje polemizujące $\mathrm{z}$ wystąpieniami propagandowymi przeciwników idei polskiego wojska. Po przeniesieniu się Wydziału Prasowego wraz z całym NPKW z Piotrogrodu do Mińska, wydawanie „Polskich Sił Zbrojnych” zostało ze względów technicznych zawieszone. Począwszy od grudnia 1917 r. zespół dziennikarski tygodnika włączono do redakcji „Żołnierza Polskiego”, który od numeru 21 z 19.12.1917 r. stał się jedynym oficjalnym organem NPKW.

Spośród ugrupowań politycznych wrogich idei polskiego wojska w Rosji prowadzących równolegle $z$ demokratami kampanię propagandową dyskredytu jącą tą ideę, jako pierwsi powołali do życia własne ogólnorosyjskie pismo socjaldemokraci ${ }^{25}$. Projekt założenia czasopisma SDKPiL w Rosji zrodził się już wczesną wiosną $1917 \mathrm{r}$., ale z uwagi na trudności finansowe jego realizacja musiała się nieco odwlec w czasie. Pierwszy numer „Trybuny”, swoim tytułem nawiązującej do wydawanej w Kraju "Naszej Trybuny”, ukazał się więc 9.06.1917 r. w Piotrogrodzie. Tygodnik powołała do życia stołeczna grupa polskich bolszewików na trzy tygodnie przed zorganizowaniem Komitetu Wykonawczego Grup SDKPiL w Rosji. Do najbliższych współpracowników kierowanej przez Juliana Leszczyńskiego redakcji należeli m.in. Stanisław Bobiński, Kazimierz Cichowski, Zbigniew Fabierkiewicz, Jakub Fenigstein, Andrzej Radziszewski, Mieczysław Warszawski i pełniący funkcję sekretarza redakcji Józef Unszlicht.

W stosunkowo licznych, mniej lub bardziej istotnych, ale zawsze jednoznacznie negatywnych wypowiedziach „Trybuny” odnośnie zagadnienia polskiego wojska w Rosji warto zwrócić uwagę na stale przewijające się akcenty. I tak we wszystkich tego typu publikacjach daje się dostrzec, że podstawowymi przesłankami wrogiego nastawienia pisma do planów stworzenia polskich formacji na gruncie rosyjskim były przede wszystkim względy programowe i polityczne. Przedstawił je w swoim artykule m.in. S. Bobiński, stwierdzając, że w Rosji pragną żołnierzy Polaków „,[...] poprowadzić do boju

24 „Polskie Siły Zbrojne”, nr 1 z 30.08.1917 r.

25 Do końca maja 1917 r. polska lewica rewolucyjna wydawała tylko dwa liczące się periodyki, tj. „Promieñ” i „Jedność Robotniczą. 
z hołotą rewolucyjną generałowie endeccy [...] tam zaś w kraju do stworzenia armii z armatami Kruppa i karabinami użyczonymi przez Austrię dąży [Tymczasowa - dop. A.M.] Rada Stanu [...]. Bagnety chłopa i robotnika z rodzinnych koszar miałyby za zadanie walczyć $z$ anarchią na wypadek rewolucji polskiej [...]. Tutaj zaś w Rosji idzie o uchowanie ludu polskiego od rozkładowych wpływów rewolucji rosyjskiej [...]. Nowa ofensywa polsko-rosyjska o wydarcie ziem polskich $\mathrm{z}$ rąk niemieckich odbyłaby się kosztem zdruzgotania kraju do szczętu [...]. Rewolucyjni socjaldemokraci w miejsce hasła silnej armii wysuwaja [zatem - dop. A.M.] postulat powszechnego uzbrojenia ludu" ${ }^{26}$. Ideę uzbrojenia ludu, jako alternatywę dla tworzenia formacji narodowych, rozwinął w tym samym numerze pisma J. Leszczyński. Wskazał on, że postulat ten można zrealizować w ramach procesu demokratyzacji armii rosyjskiej, jak też w wyniku akcji tworzenia uzbrojonej gwardii robotniczej. Ponadto redaktor naczelny "Trybuny" w ostrych słowach zaatakował zarówno środowisko politycznych rzeczników tworzenia polskiego wojska w Rosji, jak i niezbyt skutecznie w jego odczuciu zwalczających ich demokratów. Słowa krytyki pod adresem tych ostatnich miały jak się wydaje podziałać na nich mobilizująco, by w trakcie odbywającego się właśnie Ogólnego Zjazdu Wojskowych Polaków jednoznacznie wespół z lewicą rewolucyjną przeciwstawili się podjęciu uchwały o tworzeniu narodowych formacji. J. Leszczyński pisał m.in. „Imperializm współczesny zamieniając Polskę w cmentarne pobojowisko, pragnie z niej uczynić kolonię z pozorami niezawisłości [...]. Armia polska pod skrzydłami opiekuńczymi Beselera i Guczkowa będzie orężem w rękach silniejszego imperializmu, który pragnie wesprzeć rodzący się imperializm Polski. Nasza demokracja bezprzymiotnikowa (Dziennik Petrogradzki i Echo Polskie) wypowiada się przeciw armii tylko ze względów taktycznych [...]. Jedną ręką pisze laurki Radzie Delegatów Robotniczych i Żołnierskich, a drugim uchem nasłuchuje, czy nie rozlega się tętent kopyt od gościńca krakowskiego i warszawskiego" 27.

Znakomitą okazję do podjęcia zmasowanej akcji propagandowej przeciwko zwolennikom idei polskiego wojska w Rosji stworzyła secesja 12 delegatów reprezentujących na Ogólnym Zjeździe Wojskowych Polaków lewicę rewolucyjną. „Trybuna”, odpowiadając na wysuwane głównie przez prasę endecką zarzuty pod adresem secesjonistów o działalność antynarodową, niezmiennie posługiwała się internacjonalistycznymi frazesami, głosząc wszem

\footnotetext{
26 „Trybuna”, nr 1 z 9.06.1917 r.

27 „Trybuna”, nr 1 z 9.06.1917 r.
} 
i wobec, że lud „[...] żadnego militaryzmu koszar sobie nie życzy ani tu, ani w kraju" 28.

Powstałe w wyniku rewolucji lutowej możliwości utworzenia własnego organu partyjnego wykorzystała też PPS Lewica. Przy utworzonym 7.05.1917 r. Centralnym Komitecie Wykonawczym PPS Lewicy w Rosji powołany został od razu zespół redakcyjny pisma, któremu nadano nazwę „Robotnik w Rosji”. Funkcję redaktora naczelnego powierzono Józefowi Ciąglińskiemu, a współpracować z nim mieli m.in. Daniel Budniak, Feliks Kon, Stefan Królikowski, Paweł Lewinson i Władysław Matuszewski. Głównie ze względów finansowych pierwszy numer tego nieperiodycznego wydawnictwa ukazał się dopiero 20.07.1917 r. „Robotnik w Rosji” zamieszczał na swych łamach publikacje w ramach dwóch podstawowych działów tematycznych, tj. publicystycznego i partyjnego. Większość zamieszczanych w piśmie artykułów była elementem walki politycznej toczącej się w środowisku wychodźstwa polskiego w Rosji. Siłą rzeczy pośród podejmowanych tematów musiała się też znaleźć sprawa formacji narodowych. Organ prasowy PPS Lewicy w Rosji niejednokrotnie dawał wyraz swojego zainteresowania tym zagadnieniem, niezmiennie piętnując wszelkie przejawy realizacji idei polskiego wojska. Prowadzona przez pismo kampania propagandowa w tej sprawie, sądząc z braku odgłosów, nie przyniosła jednakże zakładanych rezultatów. Czy jednak mogło być inaczej skoro „Robotnik w Rosji” redagowany był w mało przystępnej formie. Pismo nie posiadało niemal wcale walorów wydawnictwa dla szerokiego ogółu czytelników, a przy tym ukazywało się nieregularnie.

Najpóźniej spośród ugrupowań politycznych zwalczających ideę polskiego wojska w Rosji powołała do życia własne, centralne wydawnictwo PPS FR. Kierujący partią na gruncie rosyjskim Tymczasowy Komitet Wykonawczy zainicjował 8.08.1917 r. wydawanie periodycznego czasopisma, któremu nadano tytuł „Głos Robotnika i Żołnierza”. Na czele zespołu redakcyjnego stanął Bronisław Siwik, a pośród jego współpracowników znaleźli się m.in. Jan Libkind, Stanisław Pławski, Tadeusz Żarski, Aleksander Prystor i Kazimierz Pużak. Ten ostatni w wyniku tarć wewnątrzpartyjnych już we wrześniu przejął po swym poprzedniku funkcję redaktora naczelnego. W odniesieniu do sprawy polskiego wojska w Rosji pismo, podobnie jak Tymczasowy Komitet Wykonawczy PPS FR, stanęło na gruncie realizacji uchwał I Konferencji Sztokholmskiej. W związku z powyższym w szeregu 
publikacjach napiętnowano myśl stworzenia własnej siły zbrojnej. W opinii redakcji „[...] armia ta, utworzona pod przewodnictwem polskiej reakcji, nie byłaby niczym innym, jak armią skierowaną przeciw Polsce niepodległej i przeciwko Rosji rewolucyjnej". W związku z powyższym wezwano Radę Delegatów Robotniczych i Żołnierskich [dalej: RDRiŻ] oraz ministra wojny Aleksandra Kiereńskiego, aby ukrócili działalność rzeczników tworzenia polskiego wojska w Rosji, zmierzająca „,...] do dezorganizowania pracy, prowadzonej przez rewolucję rosyjską nad umocnieniem armii rewolucyjnej" 29 . Czas pokazał jak bardzo szkodliwą była tego typu propaganda. Lewica niepodległościowa miała się o tym przekonać po przewrocie bolszewickim, kiedy zmieniwszy linię programową próbowała bezskutecznie agitować za tworzeniem polskiego wojska.

Zupełnie odmienną linię propagandową realizowały w odniesieniu do kwestii polskiego wojska w Rosji dwa zbliżone do ruchu demokratycznego organy prasowe, tj. „Dziennik Miński” i „Dziennik Kijowski”. Ta odmienna postawa wynikała $\mathrm{z}$ długiej drogi, jaką musiały pokonać oba pisma nim znalazły się w gronie wydawnictw zwalczających tą ideę. Pierwszy $z$ wymienionych dzienników związany był z konserwatywną Radą Polską Ziemi Mińskiej, drugi natomiast, reprezentując linię programową Stronnictwa Pracy Narodowej, początkowo pozostawał nawet półoficjalnym organem endeckiego Polskiego Komitetu Wykonawczego na Rusi. Z chwilą, gdy oba środowiska konserwatywne zacieśniły współpracę $\mathrm{z}$ ugrupowaniami demokratycznymi również związane $z$ nimi pisma musiały przejść na programowo nowe pozycje. Zatem $z$ racji na te zaszłości ton wystąpień przeciwko tworzeniu polskich formacji musiał być w nich bardziej umiarkowany. Nie bez znaczenia w tym względzie pozostawał też fakt, że mińszczyzna i kijowszczyzna stały się ośrodkami organizowania polskich korpusów. Zwłaszcza „Dziennik Kijowski" starał się wyraźnie nie opowiadać po którejkolwiek ze stron toczącego się sporu, ograniczając się do publikowania informacji i dokumentów. Niemniej jednak i przy okazji przekazywania suchych relacji, czy zamieszczania dokumentów dotyczących tworzenia polskich formacji wojskowych, obie gazety pośrednio, chociażby powołując się na opinie zamieszczane na łamach bratnich stołecznych organów, podważały zasadność polskiej akcji wojskowej w Rosji.

29 „Głos Robotnika i Żołnierza”, nr 1 z 8.08.1917 r. 